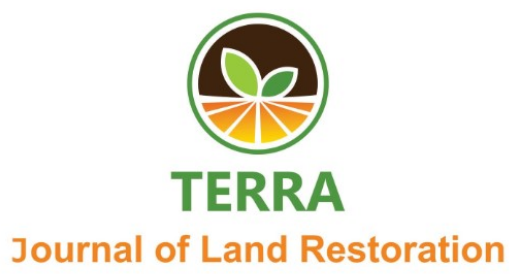

\title{
Relationship Characteristics Soil, Fertilization and Outcome of Rice in Village Lubuk Pinang, Mukomuko
}

\author{
Weri Akmaldi ${ }^{1}$, M. Faiz Barchia ${ }^{2}$, Dwi Wahyuni Ganefianti ${ }^{1}$ \\ ${ }^{1}$ Agronomy Department, Faculty of Agriculture, University of Bengkulu \\ ${ }^{2}$ Soil Science Department, Faculty of Agriculture, University of Bengkulu (Corresponding author) \\ e-mail:faizbarchia@unib.ac.id
}

\begin{abstract}
This study aims to determine the close relationship between the characteristics of paddy soils and rice yields in Lubuk Pinang, the Manjunto Air Irrigation area, and to determine the level of applied technology of farmers and rice yields in Lubuk Pinang, the Air Manjunto Irrigation area. This research was conducted in April 2018 until June 2018 in Lubuk Pinang, Lubuk Pinang District, Mukomuko Regency. The study was conducted by survey method. Data was collected through direct observation in the field and soil analysis at the Soil Science Laboratory of Bengkulu University. The results showed that the coefficient regression soil $p H\left(X_{1}\right)$ is 0.208 to 0.875 sig $t$ values are not real in the statistics. The regression coefficient cation exchange capacity $\left(X_{2}\right)$ is -0.018 with $t$ sig value 0,781. Regression coefficient peat depth $\left(X_{3}\right)$ is -0.002 to 0.814 sig $t$ values are not real in the statistics. Regression coefficient levels of soil organic $C\left(X_{4}\right)$ is -0.507 to 0.307 sig $t$ values are not real in the statistics.
\end{abstract}

Keywords: rice, peat, production, C-organic, peat depth, $\mathrm{pH}$

\section{INTRODUCTION}

Lowland rice (Oryza sativa L.) It is the main food crop in Indonesia. About $90 \%$ of Indonesia's population uses rice as a staple food. The contribution of rice in filling the nutritional needs is even greater at the lower-income level of the population (Koswara \& Sutrisno, 2009). Rice is a food source of energy that has a carbohydrate content is high, but protein a low. The nutritional content of rice per $100 \mathrm{~g}$ of material is from 0.40 to $7.70 \mathrm{~g}$ fiber, 6.93 to $8.70 \mathrm{~g}$ protein, $0.58 \mathrm{~g}$ of fat,and79.34 $\mathrm{g} \mathrm{c}$ arbohydrates (Suliartini et al., 2011). Based on BPS data, national rice production in 2014 reached 70.846 million tons and increased in 2015 to 75.397 million tons, this increase in production has not been able to meet national consumption needs, whereas for rice production in Bengkulu decreased from 5.93 million tons in 2014 and 5.78 million tons in 2015. Decreasing the amount of production, which reached 1.5 million tons, is something that must be increased so that the need for rice is always fulfilled (BPS 2015).

Peatlands are classified as marginal land, and fragile with productivity is usually low and very easily damaged. Agricultural development on peat swamp to support sustainable development requires careful and meticulous planning, the application of appropriate technology, and proper management. Conservation and optimization of peat swampland use according to its characteristics require information onitstype,characteristics, and distribution (Widjaja, 1992). Whereas for mineral soils, the productivity level is quite good, because the $\mathrm{pH}$ of the red soil is better than peat soil, so farmers use this land more than peat, both in terms of processing and the level of production produced by planted crops.

Lubuk Pinang Village, which is one of the subdistricts included in the administrative area of the Mukomuko Regency. This sub-district is located at an altitude of 14-32 meters above sea level, almost all of its territory is crossed by a watershed, known as the Air Montino river. The majority of the population work as oil palm farmers and rice farmers. The area of rice cultivation in this area is not known with certainty, but based on BPS data, it is known that the total harvest was 26,100 tons in 2015 in the Lubuk Pinang sub-district (BPS, 2017).

Land suitability is a description of the level 
of land suitability against a particular use. The land suitability assessment will be carried out in two conditions, actual conditions and potential conditions. The actual condition assessment is done during the field survey, while ratings of condition potential to do when making improvement an area (FAO, 1976).

Actual land suitability is land suitability based on data on biophysical properties of land or land resources before the land is given the inputs needed to overcome obstacles. Potential land suitability illustrates land suitability that will be achieved if improvements are made (Ritung et al., 2007). Determination suitability is done by comparing the characteristics and quality of land with land use requirements for a particular crop (Wati et al ., 2013).

Land suitability value is determined by the presence of inhibiting factors and the level of these inhibiting factors. The potential and suitability of peatlands for agriculture are very limited by the main factors, namely drainage, carrying capacity, maturity, and thickness of peat soils and chemical properties which are generally classified as low to very low, especially with substratum sulfidic material and quartz sand (Kartawisastra, 2016). Nagur's research results (2017) produce that in organic land, the correlation values are obtained between $\mathrm{KL}$, organic $\mathrm{C}$, total $\mathrm{N}$, available $\mathrm{P}, \mathrm{K}$ available $\mathrm{KPK}, \mathrm{Eh}$, and soil hardness to production. Moisture content was positively correlated not significantly with rice production $(\mathrm{r}=$ 0.385 ), organic $\mathrm{C}$ was positively correlated not significantly with rice production $(\mathrm{r}=0.268)$, total $\mathrm{N}$ was not positively correlated significantly with rice production $(\mathrm{r}=0.295)$, $\mathrm{P}$ provided negative correlation significantly with rice production $(r=-0.302)$, available $\mathrm{K}$ is not a significantly negative correlation with rice production $(\mathrm{r}=-0,283)$, KPK has no positive correlation with rice production $(\mathrm{r}=0.253)$, Eh has no positive, positive correlation with rice production $(\mathrm{r}=0.023)$, soil hardness is positively correlated not significantly with rice production $(\mathrm{r}=0.042)$.

This study aims to determine the close relationship between soil characteristics, level of N, P, K, Dolomite fertilization and rice yield in Lubuk PinangMukomuko District

\section{MATERIAL AND METHOD}

This research was conducted in April 2018 until June 2018 in Lubuk Pinang, Lubuk Pinang District, Mukomuko Regency. Analysis of variables through direct observation in the field and soil analysis at the Soil Science Laboratory, Bengkulu University.

The materials used in this research are annual rainfall data and research reports, farmer interview forms, and rice yield data. The tools used in this research consisted of field knives, ground drill, folding meter, GPS
(Global Positioning System), Munsell's book Soil Color Charts, and other tools needed in the field. Laboratory instruments for chemical analysis of soil samples.

The stages of the field survey are the stages of collecting soil, agro-climate, and crop data that can be measured directly in the field using survey methods, as well as interviewing farmers to obtain data on rice yields. Analysis and interpretation of data obtained through the chemical analysis of soil samples in the laboratory to obtain chemical data of land sites. After all, data has been collected, proceed with data processing with multiple linear regression methods to determine the relationship of each unit of research land.

In the pre-survey phase, among others: gathering the necessary equipment, collecting the materials used, completing all licensing documents to support the smooth implementation of research as a basis for conducting field surveys. Field surveys include several activities, namely observation, measurement, soil sampling, to determine the physical and chemical variables of the land and farmer interviews to get other supporting data. At this stage, the data obtained were analyzed using multiple linear regression methods to determine the relationship of some land characteristics with rice production. The plant variables observed in the field are rice yields that describe the number of farm products harvested in one area of land in one production cycle.

Soil variables observed in the field include soil depth, variables analyzed in the laboratory are nutrient retention (CEC, $\mathrm{pH}$, and $\mathrm{C}$-Organic). Climate factors are supporting data that use secondary data, including air humidity, air temperature, and rainfall obtained from the local climatology station.

\section{RESULT AND DISCUSSION}

Administratively, Lubuk Pinang District is located in Mukomuko Regency. Geographically, the area of Lubuk Pinang District in the north is bordered by Pesisir Selatan Regency, West Sumatra Province, in the South, bordered by Air Manjunto District, in the east bordering V Koto District, and in the West bordering Koto XIV District. The width of the Lubuk Pinang sub-district is 9271 ha, the topography of this sub-district tends to be flat with a height of between 14 - 32 meters above sea level (BPS, 2017).

The type of soil that develops in this area is dominated by Histosol (peat) and Ultisol, and peat soil is soil formed from a pile of remnants of dead plant tissue that formed in anaerobic conditions due to very high water saturation. The main characteristics of peat soils are rich in organic matter (C-Organic $>$ $18 \%$ ), thickness above $50 \mathrm{~cm}$, nutrient-poor, and high acidity (Agus \& Subiksa, 2008). 
Farmers at the study site used several rice varieties, namely Inpari-32, Ciliwung, IR-64, Mekongga, and Ciherang. Based on the description of Inpari-32 variety has an average yield of 6.3 tons/ha with a potential yield of 8.42 tons / ha, ciliwung has an average yield of 4.8 tons/ha with a potential yield of 6.5 tons / ha, IR64 has an average yield of 5.0 tons/ha with a potential yield of 6.0 tons/ha, hollow has an average yield of 6.0 tons/ha with a potential yield of 8.4 tons/ha, and Ciherang has an average yield of 6 tons/ha with a potential yield of 8.5 tons/ha. While based on the results of the study, it was seen that the production of Inpari 32 varieties ranged from 4.89 to 9.52 tons ha, Ciliwung varieties ranged from 2.93-8.86 tons/ha, IR -64 by 6.84 tons/ha, cavity ranged from $2,22-2.24$ tons/ha, and Ciherang ranges from 2.25-7.43 tons/ha. While in terms of land management, there are respondents who manage the land traditionally using a hoe or in a modern way using a tractor. In controlling pests, farmers at the research location prefer to use chemical control.

The research data observed included soil $\mathrm{pH}$, CEC, C-organic, peat depth, N, K, P, dolomite fertilizer, and rice production. Soil $\mathrm{pH}, \mathrm{CEC}$, and Corganic values were analyzed at the Soil Science Laboratory of the University of Bengkulu, while peat depth and rice production were measured in the field.

The results showed that the $\mathrm{pH}$ value of peat ranged from 4.7 to 6.1 , with an average of 5.51. The criteria for soil $\mathrm{pH}$ values at the study site are quite acidic. The results of the study are higher than the statement of Rachim (1995) that the yield of tropical peatlands is generally high ( $\mathrm{pH} 3-5)$, caused by hydrolysis of organic acids, which are dominated by fulvic acid and humic. This is presumably because farmers at the study site used dolomite lime as fertilizer, thereby increasing the $\mathrm{pH}$ value of peat soils. According to Aryanti et al. (2016), dolomite limestone contains $\mathrm{Ca}$ and $\mathrm{Mg}$ elements, where both of these elements shift the $\mathrm{H}^{+}$position on the colloidal surface, thereby neutralizing the acidity of the soil. Besides, according to Nurhayati (2014), the hydrolysis reaction can release $\mathrm{OH}$ ions ${ }^{-}$which affect the increase in soil $\mathrm{pH}$. In line with the statement of Maftu'ah et al. (2013) that lime provides $\mathrm{OH}^{-}$supply to the soil solution, which reacts with $\mathrm{H}^{+}$to water and causes $\mathrm{H}^{+}$levels to decrease so that soil $\mathrm{pH}$ increases.

CEC values at the study sites ranged from 29.6 $81.90 \mathrm{Cmol}(+) / \mathrm{kg}$ with an average of $60.55 \mathrm{Cmol}$ $(+) / \mathrm{kg}$. Criterion CEC value at the research location is high to very high. According to Kumalasari et al. (2011) that the high organic matter can increase the absorption and cation exchange capacity. This happens because the weathering of organic material will produce humus (organic colloids), which are a source of negative soil charge so that it has a surface that can hold nutrients and water. With increasing cation exchange capacity, it can hold nutrients.

$\mathrm{C}$-organic levels in the study area ranged from $37.70 \%-53.34 \%$, with an average of $45.56 \%$. The value of $\mathrm{C}$-organic content at the research location is

Table 1. Results of observations of $\mathrm{pH}, \mathrm{CEC}, \mathrm{C}-$ Organic, peat depth, and rice production at the study site

\begin{tabular}{|c|c|c|c|c|c|c|c|c|}
\hline \multirow[t]{2}{*}{$\begin{array}{c}\text { Site } \\
\text { samples }\end{array}$} & \multirow[t]{2}{*}{$\mathrm{pH}$} & \multirow{2}{*}{$\begin{array}{c}\text { CEC } \\
(\mathrm{cmols}(+) / \mathrm{k})\end{array}$} & \multirow{2}{*}{$\begin{array}{c}\text { Peat Depts } \\
(\mathrm{cm})\end{array}$} & \multicolumn{4}{|c|}{ Fertilizers Applications (kgs/ha) } & \multirow[t]{2}{*}{$\begin{array}{c}\text { Rice } \\
\text { Yields } \\
\text { (tons/ha) }\end{array}$} \\
\hline & & & & $\mathrm{N}$ & $\mathrm{P}$ & K & Dolomite & \\
\hline 1 & 6.1 & 29.68 & 36 & 200 & 150 & 100 & 600 & 7.2 \\
\hline 2 & 5.9 & 34.54 & 21 & 200 & 200 & 200 & 750 & 9.5 \\
\hline 3 & 6.3 & 38.02 & 15 & 200 & 200 & 200 & 750 & 8.9 \\
\hline 4 & 6.1 & 43.60 & 84 & 200 & 150 & 150 & 500 & 6.8 \\
\hline 5 & 5.8 & 42.18 & 76 & 100 & 75 & 50 & 100 & 2.9 \\
\hline 6 & 4.7 & 50.43 & 85 & 150 & 100 & 150 & 500 & 6.7 \\
\hline 7 & 4.7 & 69.03 & 129 & 50 & 50 & 50 & 200 & 2.2 \\
\hline 8 & 5.0 & 80.16 & 107 & 200 & 150 & 200 & 750 & 7.5 \\
\hline 9 & 5.1 & 63.80 & 103 & 75 & 50 & 50 & 200 & 2.6 \\
\hline 10 & 5.4 & 66.12 & 167 & 150 & 100 & 100 & 400 & 5.6 \\
\hline 11 & 5.1 & 77.72 & 153 & 50 & 50 & 50 & 300 & 2.8 \\
\hline 12 & 5.6 & 74.81 & 175 & 50 & 50 & 50 & 150 & 2.5 \\
\hline 13 & 5.6 & 81.90 & 246 & 100 & 75 & 75 & 200 & 3.9 \\
\hline 14 & 5.6 & 77.74 & 335 & 100 & 75 & 75 & 600 & 4.8 \\
\hline 15 & 5.7 & 78.59 & 370 & 100 & 100 & 100 & 500 & 4.9 \\
\hline \multicolumn{2}{|c|}{ Average: 5.51} & 60.55 & 140.13 & 128 & 105 & 107 & 433 & 5.3 \\
\hline
\end{tabular}


very high. In line with the results of research by Manurung et al. (2018) that the levels of C-organic peat soils are classified as very high, ranging between $34.59 \%-56.07 \%$. According to Hardjowigeno (2003), the process of decomposition of peat soils under anaerobic conditions causes the accumulation of layers of organic matter, which contribute to the $\mathrm{C}$-organic content of the soil.

The depth of the peat at the study site ranged from $15 \mathrm{~m}-370 \mathrm{~m}$ with an average depth of $140.3 \mathrm{~m}$. Criteria for the depth of research between shallow to deep peat. According to Wahyunto et al., (2005) dividing peat thickness into four classes, namely shallow $(50-100 \mathrm{~cm})$, moderate $(>100-200 \mathrm{~cm})$, deep $(>$ $200-400 \mathrm{~cm})$, and very deep $(>400 \mathrm{~cm})$. Based on its depth, the soil at the study site is divided into 4 types, namely depth of $15-36 \mathrm{~cm}$ located at points 1 3 classified as mineral soil, $76-85 \mathrm{~cm}$ located at points 4-6 classified as shallow peat, $103-175 \mathrm{~cm}$ located at the point 7-12 classified as moderate peat, and $246-370 \mathrm{~cm}$ located at point $13-15$ classified as deep peat.

Multiple regression analysis relates to the study of the dependence of a dependent variable on one or more independent variables in order to find out how much influence the independent variable has on the dependent variable. The results of multiple linear regression analysis between independent variables namely soil $\mathrm{pH}\left(\mathrm{X}_{1}\right)$, cation exchange capacity $\left(\mathrm{X}_{2}\right)$, peat depth $\left(\mathrm{X}_{3}\right)$, soil $\mathrm{C}$-organic content $\left(\mathrm{X}_{4}\right)$, dose $\mathrm{N}\left(\mathrm{X}_{5}\right)$, dose $\mathrm{P}\left(\mathrm{X}_{6}\right), \mathrm{K}$ dose $\left(\mathrm{X}_{7}\right)$, and dolomite dose $\left(\mathrm{X}_{8}\right)$, as well as the dependent variable namely rice production presented in Table 2 .

Based on the results of multiple linear regression tests presented in Table 2, the relationship between soil $\mathrm{pH}\left(\mathrm{X}_{1}\right)$, cation exchange capacity $\left(\mathrm{X}_{2}\right)$, peat depth $\left(\mathrm{X}_{3}\right)$, and soil C-organic content $\left(\mathrm{X}_{4}\right)$ dose $\mathrm{N}\left(\mathrm{X}_{5}\right)$, dose $\mathrm{P}\left(\mathrm{X}_{6}\right)$, dose $\mathrm{K}\left(\mathrm{X}_{7}\right)$, and dolomite $\left(\mathrm{X}_{8}\right)$ dose with rice production $(\mathrm{Y})$ are described in the equation: $\quad \mathrm{Y}=60.1+0.679 \mathrm{X}_{1}-0.01 \mathrm{X}_{2}-0.0000005 \mathrm{X}_{3}$ $0.0058 \mathrm{X}_{4}+0.004 \mathrm{X}_{5}+0.008 \mathrm{X}_{6}+0.017 \mathrm{X}_{7}+0.004 \mathrm{X}_{8}$

Partially, the influence of eight (8) independent variables on rice production seen that the coefficient regression soil $\mathrm{pH}\left(\mathrm{X}_{1}\right)$ is 0.679 to $0.099 \mathrm{t}$ value sig. This means that each increase in soil $\mathrm{pH}$ by 1 unit will increase rice yield by $679 \mathrm{~kg} / \mathrm{ha}$ with no significant effect $(\mathrm{P}>0.05)$. The value of the cation exchange capacity regression coefficient $\left(\mathrm{X}_{2}\right)$ is 0.01 with the value of tig sig 0.538 , which means that each increase of $1 \mathrm{me} / 100$ cation exchange capacity will reduce rice yield by $10 \mathrm{~kg} / \mathrm{ha}$ with no significant effect (non-significant). The regression coefficient value of peat depth $\left(\mathrm{X}_{3}\right)$ is -0.00005 with a $\mathrm{t}$ value of sig 0.981 , which means that every $1 \mathrm{~m}$ increase in peat depth will reduce rice yield by 0,000 $05 \mathrm{~kg} / \mathrm{ha}$ with no significant effect (non-significant). Value coefficient regression levels of soil organic C
$\left(\mathrm{X}_{4}\right)$ are -0.058 with a $\mathrm{t}$ value sig 0,170 , which means that every $1 \%$ increase in soil organic $\mathrm{C}$ will decrease the yield of rice by $58 \mathrm{~kg} / \mathrm{ha}$ with no real influence (non- significant). Value coefficient regression levels of fertilizer $\mathrm{N}\left(\mathrm{X}_{7}\right)$ were 0.017 with a value of $\mathrm{t}$ sig 0,043 , which means that every increase of $1 \mathrm{~kg} / \mathrm{ha}$ dose of fertilizer $\mathrm{N}$ will shortly increase rice yield by $17 \mathrm{~kg} / \mathrm{ha}$ with real influence. The value of the regression coefficient of fertilizer dosage level $\mathrm{P}\left(\mathrm{X}_{6}\right)$ is 0.008 , with a tig value of 0.562 . This means that every $1 \mathrm{~kg} /$ ha increase in the dose of $P$ fertilizer will increase rice yield by $8 \mathrm{~kg} / \mathrm{ha}$ with no significant effect (non-significant). Value coefficient regression levels of fertilizer $\mathrm{K}\left(\mathrm{X}_{5}\right)$ are 0.004 with a t value sig 0,685 , which means that every increase of $1 \mathrm{~kg} / \mathrm{ha}$ dose of fertilizer $\mathrm{K}$ will shortly increase rice yields by $4 \mathrm{~kg} / \mathrm{ha}$ with no real influence (non- significant). The value of the regression coefficient of dolomite lime dosage level $\left(\mathrm{X}_{8}\right)$ is 0.004 with a $\mathrm{t}$ sig value of 0.18 , which means that every $1 \mathrm{~kg} / \mathrm{ha}$ increase in dolomite lime dose will increase rice yield by 4 $\mathrm{kg} / \mathrm{ha}$ with real influence.

Table 2. Results of multiple linear regression tests relating the characteristics of soil and fertilization with rice production

\begin{tabular}{|c|c|c|c|c|c|c|}
\hline \multirow[t]{3}{*}{ No } & \multirow[t]{3}{*}{ Model } & \multicolumn{2}{|c|}{ Unstandardized } & \multirow{3}{*}{$\begin{array}{c}\text { Standardized } \\
\text { Coefficients } \\
\text { Beta }\end{array}$} & \multirow{3}{*}{$\mathrm{t}$} & \multirow{3}{*}{ Sig. } \\
\hline & & \multicolumn{2}{|c|}{ Coefficients } & & & \\
\hline & & $\mathrm{B}$ & Std Error & & & \\
\hline & (Constant) & 60.1 & 20.562 & & -10.900 & $0.049^{*}$ \\
\hline 1 & $\mathrm{pH}$ & 0.679 & 0.367 & -0.159 & -0.647 & 0.099 \\
\hline 2 & CEC & -0.010 & 0.015 & -0.073 & -0.025 & 0.538 \\
\hline 3 & Peat depth & -0.00005 & 0.002 & -0.002 & -10.530 & 0.981 \\
\hline 4 & Corganic & -0.058 & 0.038 & -0.107 & 0.423 & 0.170 \\
\hline 5 & $\mathrm{~N}$ fertilizer & 0.017 & 0.007 & 0.415 & 20.474 & $0.043^{*}$ \\
\hline 6 & P fertilizer & 0.008 & 0.013 & 0.162 & 0.609 & 0.562 \\
\hline 7 & $K$ fertilizer & 0.004 & 0.009 & 0.091 & 0.423 & 0.685 \\
\hline 8 & Dolomite & 0.004 & 0.001 & 0.372 & 30.78 & $0.018^{*}$ \\
\hline
\end{tabular}

In general, the results of the study showed that soil $\mathrm{pH}$, cation exchange capacity, peat depth, and $\mathrm{C}$ -organic soil partially had no significant effect on rice yield . this is alleged because peat soils have soil $\mathrm{pH}$, cation exchange capacity, peat depth, and $\mathrm{C}$ -organic soil are less compatible with rice so that their growth and production are not inhibited. In line with the statement (Salsi, 2011) that peatlands are marginal land for agriculture because of their low fertility, highly acidic nature, high cation exchange capacity, low base saturation, low $\mathrm{K}, \mathrm{Ca}, \mathrm{Mg}, \mathrm{P}$ and microelements such as $(\mathrm{Cu}, \mathrm{Zn}, \mathrm{Mn}, \mathrm{B})$ are also low. Limited land of mineral land, causing the extensification of agriculture to peatlands, can not be avoided.

Agricultural development from peatlands faces obstacles, including high levels of organic acids. The bad influence of toxic organic acids can be 
reduced by water management technology and the addition of materials that contain lots of polyvalent cations such as $\mathrm{Fe}, \mathrm{Al}, \mathrm{Cu}$, and $\mathrm{Zn}$ (Ratmini, 2012). Krisnohadi (2011) added that organic compounds which are toxic and inhibit plant growth, thus the need for the addition of ameliorant material to overcome the problem of peat soil fertility.

Soil reaction $(\mathrm{pH})$ is a chemical characteristic of soil that is very important to know because of its very broad implications for soil quality and land productivity (Bohn et al., 2005). Soil reaction is closely related to nutrient solubility, plant tolerance, nutrient absorption, microorganism activity, and ion fixation in the soil. Soil reactions indicate acidity or alkalinity of the soil expressed by the $\mathrm{pH}$ value. The $\mathrm{pH}$ value indicates the amount of hydrogen ion concentration $\left(\mathrm{H}^{+}\right)$in the soil. The general influence of $\mathrm{pH}$ on the crop is the availability of nutrients in the soil (Kirnadi et al., 2014). If the soil reacts sourly, some plants cannot grow well because of their reduced tolerance, whereas if the soil is too acidic, $\mathrm{Al}$ and $\mathrm{Fe}$ poisoning often occur, and fixation of anions such as phosphate and sulfate often occurs. Nutrient uptake and plant growth are generally less than optimal if the soil reacts sourly (Mengel \& Kikrby, 2007 ). Riyandani's research results (2016) showed that peatlands in the Arut Selatan Subdistrict of West Waringin City District had land suitability with sufficient criteria following the limiting factor of soil $\mathrm{pH}$ values.

The results of multiple linear regression tests showed that each increase in soil $\mathrm{pH}$ by 1 unit would increase rice yield by $679 \mathrm{~kg} / \mathrm{ha}$. P Increased soil $\mathrm{pH}$ will cause increased more soil chemical properties so that the rice yield increased. In line with the statement of Djamhari (2009) that an increase in rice production on moist swampland can be achieved through an increase in soil $\mathrm{pH}$. The results of Ardi et al. (2017) show that the increase in soil $\mathrm{pH}$ tends to be followed by the availability of macronutrients $(\mathrm{N}$, $\mathrm{P}, \mathrm{K})$.

The cation exchange capacity (CEC) of soil can be defined as the ability of a colloidal soil to absorb and exchange cations. Cation exchange capacity is the number of cations that are absorbed or released from the surface of clay or humus colloids in milliequivalents per $100 \mathrm{~g}$ of soil or humus samples (Hakim et al., 1986). Soils that have moderate to high organic matter, usually have a CEC that is relatively higher in soil than soils that are low in organic matter (Suriadikarta et al., 2002). CEC value of land is very diverse and depends on the nature and characteristics of the land. The size of the CEC is influenced by soil reaction, texture or amount of clay, clay mineral species, organic matter, and liming or fertilizing (Hardjowigeno, 2003). The results of Waluyo \& Djamhari's research (2011) show that peatlands in the Tanjung Elai area have land suitability with sufficient criteria following the limiting factor of the CEC value.

The test results in the regression linear showed that every increase of $1 \mathrm{me} / 100$ cation exchange capacity would reduce rice yield by $10 \mathrm{~kg} / \mathrm{ha}$. This is because peat soils have very high CEC values. On the other hand, the very high CEC value of land affects the disruption of rice growth, thereby reducing rice yield. Therefore the increase in CEC will be followed by a decrease in rice production. According to Noor (2001), the high value of this CEC was also accompanied by a low base saturation (KB) of $8 \%$. Ca, $\mathrm{Mg}, \mathrm{K}$, and $\mathrm{Na}$ cations of the sorption complex are exchanged by $\mathrm{H}$ ions so that the $\mathrm{IH}$ will dominate the rice complex.

The test results from the regression linear showed that every increase of $1 \mathrm{~m}$ depth of the peat would lower the rice yield of $00.05 \mathrm{~kg} / \mathrm{ha}$. This is because the higher the depth of the peat, the lower the fertility of the peat due to the lower $\mathrm{pH}$ and retention of the soil. According to Najiyati et al. (2004), acidity peat tends to increase with depth of peat. The upper layers of shallow peat tend to have a higher $\mathrm{pH}$ than thick peat. Liming peat soils to increase $\mathrm{pH}$ is not very effective because of low peat Al levels. Sani (2011) goes on to say that shallow peat has a higher $\mathrm{pH}$ and $\mathrm{N}$ content than deep peat. The research result Maas et al. (2000) showed that peat moss has a land suitability criteria $\mathrm{S}_{3}$ (corresponding conditional) by a factor delimiter peat thickness.

Also, the deeper the peat depth, the lower the level of peat maturity. Susandi et al. (2015) showed that peat maturity at a depth of $0-50 \mathrm{~cm}$ and $50-100$ $\mathrm{cm}$ were classified as hemic peat with a fiber content of $41 \%$ and $61 \%$, respectively, whereas the depth of $100-150 \mathrm{~cm}$ was classified as fibric peat $(70.25 \%$ fiber content).

C-organic soil shows the level of organic matter contained in the soil. Peat soils usually have higher levels of organic $\mathrm{C}$ than mineral soils. C-organic levels indicate the level of peat maturity. Peat from the type of fibric level of C-organic levels will be higher than sapric and hemic (Soewandita, 2008).

The test results from linear regression show that every $1 \%$ increase in soil organic $\mathrm{C}$ will decrease the yield of rice by $58 \mathrm{~kg} / \mathrm{ha}$. This is because high levels of soil C-organic indicate that the decomposition process is not perfect. Also, the higher the Corganic level of peat soils will have an impact on the higher $\mathrm{C} / \mathrm{N}$ ratio so that the availability of other nutrients is lower. Consequently, rice production will decrease. According to Mario (2002), the process of peat soil decomposition has not occurred perfectly because the dominant peat state is always saturated. These conditions cause peat soils to have a low fertility and $\mathrm{pH}$ level.

Based on the multiple linear regression equation, it shows that each increase of $1 \mathrm{~kg} / \mathrm{ha}$ of $\mathrm{N}$ fertilizer dose will increase rice yield by $17 \mathrm{~kg} / \mathrm{ha}$ with a 
real effect. The increase in production due to $\mathrm{K} \mathrm{nu}-$ trients has an important role for plants. According to Sutedjo (2002) that the element K has a role to help root development so that it can increase nutrient uptake by plants, help in the formation of plant seeds to be more contained and dense, help the formation of proteins and carbohydrates, reduce grain loss so that the grain produced is high, and indirectly helps to activate the enzyme. Dobermann \& Fairhust (2000) add that nutrient $\mathrm{K}$ also has an important role for plants to improve photosynthesis, save water use, maintain turgor, form strong stems, act as an activator for various enzyme systems, and strengthen roots.

Plants lacking $\mathrm{K}$ show stunted growth. The root system of the plant is bad / obstructed. Plant stems become weak. Seeds and small fruit and have an abnormal shape. In conjunction with plant physiological processes, $\mathrm{K}$ deficiency can lead to the accumulation of soluble carbohydrates and reduced sugars, inhibited protein synthesis, inhibited utilization of respiratory substrate, phosphorylation oxidation velocity, and decreased photophosphorylation. So if it is concluded that $\mathrm{K}$ deficiency in plants is closely related to the metabolism of $\mathrm{N}$ and carbohydrates (Winarso, 2005).

Based on the multiple linear regression equation, it shows that every $1 \mathrm{~kg} / \mathrm{ha}$ increase in the dose of $P$ fertilizer will increase rice yield by $8 \mathrm{~kg} / \mathrm{ha}$ with a real effect. In line with the results of the study Syamsiyah et al. (2009) that P fertilization has a very significant influence in increasing rice yields in the Kulon Progo beach sand fields.

The increase in rice productivity along with the increase in the dose of $\mathrm{P}$ fertilizer is since the $\mathrm{P}$ nutrient function directly influences seed formation. The higher the P uptake of plants, the better the formation of seeds. According to Rauf et al. ( 2000) the influence of the $\mathrm{P}$ element on rice plants is as follows: spur the formation of flowers, reduce abortion, support the development of fine roots and hair roots, strengthen the straw so that it does not easily fall and improve grain quality. The phosphorus deficiency causes stunted growth, the number of children $\mathrm{k}$ 's slightly tapered and dark green leaves.

Based on the multiple linear regression equation, the $\mathrm{N}\left(\mathrm{X}_{3}\right)$ fertilizer regression coefficient is 0.017 , with a tig value of 0.043 . This means that every increase of $1 \mathrm{~kg} / \mathrm{ha}$ dose of fertilizer $\mathrm{K}$ will increased rice yields by $4 \mathrm{~kg} / \mathrm{ha}$ with real influence. The most important role of $\mathrm{N}$ elements in rice plants is as a compiler or as a basic ingredient of protein and the formation of chlorophyll because $\mathrm{N}$ has the function of making plant parts greener, contains many green grains and most importantly in the process of photosynthesis, accelerates the growth of plants that in this case increasing the height of plants and number of seedlings, increasing the size of leaves and grain size and improving the quality of plants and grain, increasing levels of rice protein, increasing the amount of grain and the percentage of the amount of filled grain (Dobermann \& Fairhust, 2000).

According to Adil et al. (2005) that $\mathrm{N}$ functions as chlorophyll forming, which plays an important role in the process of photosynthesis. The higher the administration of $\mathrm{N}$ (up to its optimum limit), the amount of chlorophyll formed will increase. Nugroho (2015) added that the function of $\mathrm{N}$, in addition to stimulatingplant growth, also gives the leaves a green color. The darker green leaves on the plant maize showed higher nitrogen that is absorbed plant. The high uptake element $\mathrm{N}$ by the plant is expected will increase the weight of dried plants and also the results of the harvest.

Based on the multiple linear equation coefficient regression doses of dolomite $\left(\mathrm{X}_{4}\right)$ is 0.004 to $0.042 \mathrm{t}$ value sig. This means that every $1 \mathrm{~kg} / \mathrm{ha}$ increase of dolomite lime dose will increase rice yield by $4 \mathrm{~kg} / \mathrm{ha}$ with a real effect. This is suspected because dolomite lime can increase soil $\mathrm{pH}$ so that the availability of nutrients increases. According to Makarim et al. (2007) states that the application of lime can neutralize the adverse effects of excess soluble Al High al will inhibit root growth so that it will affect nutrient absorption. The provision of dolomite will directly add $\mathrm{Ca}$ and $\mathrm{Mg}$ in the soil.

Nurhayati (2014) explains that lime affects the increase in soil $\mathrm{pH}$. Soil with a $\mathrm{pH}$ of 6.5-7 causes microorganisms to be able to grow and develop properly. The availability of microorganisms can hydrolyze phospholipids in the presence of phosphate enzymes that can convert phosphorus compounds into plants that are proven to be able to provide a good effect on the growth of peanut plants. Following the opinion of Sarief (1986) which states that phosphorus plays a role in arranging the body of plants and several coenzymes that play a role in metabolic activity. With the increase in metabolic activity, the organic material that is formed is sufficiently available so that carbohydrates are produced and converted into plant organs.

\section{CONCLUSION}

Based on the results of the study, it can be concluded that the characteristics of the soil $(\mathrm{pH}$ soil, $\mathrm{CEC}$, the depth of peat, $\mathrm{C}$ - organic), as well as the dosage of fertilizer $\mathrm{K}$ and $\mathrm{P}$ effect, is not noticeable to the results of rice. The provision of fertilizer $\mathrm{N}$ and lime dolomite effect on the real against the results of therice. Each increment of $1 \mathrm{~kg} / \mathrm{ha}$ dose of fertilizer $\mathrm{N}$ then will increase the result of rice amounted to 17 $\mathrm{kg} / \mathrm{ha}$. Each increment of $1 \mathrm{~kg} / \mathrm{ha}$ dose of lime dolomite will improve the results of rice amounting to 4 $\mathrm{kg} / \mathrm{ha}$. 


\section{References}

Agus, F. \& Subiksa, I.G.M. (2008). Peatlands: Potential for Agriculture and Environmental Aspects. Center for Soil Research and the World Agroforestry Center (ICRAF). Bogor.

Ardi, I., Razali, \& Hanum, H. (2018). Identification of nutrient status and rice production in the terraced and non-terraced rice fields in the District of Onos Runggu Samosir. The USU FP Agroecotechnology Journal., 5(2), 338347.

Aryanti, E., Yulita, Rani, A. \& Annisava. (2016). Provision of several ameliorant for changes in the chemical properties of peatlands. Journal of Agrotechnology. 7(1), 19-26

Bohn, H.L., Mc Neal, B.L. \& O'Connor, G.A. (2005). Soil Chemistry. John Wiley \& Sons, New York.

Central Bureau of Statistics Mukomuko District. (2017). Subdistrict Lubuk Pinang in Numbers 2017. Mukomuko.

Central Bureau of Statistics. (2017). National Rice Production in Figures 2017.https:// www.bps.go.id/linkTableDinamis/view/ $i d / 865$. Accessed September 28, 2017.

Djamhari, S. 2009. Increased rice production on lebak land as an alternative in developing agricultural land outside of Java. Jurnal Science and

Technology of Indonesia. 11(1), 64-69.

Dobermann, A. \& Fairhurst, T. (2000). Nutrient disorders and nutrient management. IRRI and Potash \& PPI/PPIC. Manila, Philippines.

FAO. (1976). A Framework for Land Evaluation. FAO Soils Bulletin No. 32. Food and Agricultural Organization. Rome

Hardjowigeno, S. 2003. Soil Classification and Pedogenesis. Akademika Pressindo, Jakarta.

Hakim, N., Nyakpa, M.Y., Lubis, A.M., Nugroho, S.G., Diha, M.A., Hong, G.B. \& Bailey, H.H. (1986). Basics of Soil Science. University of Lampung, Lampung.

Koswara \& Sutrisno. (2009). Rice Processing Technology (Theory \& Practice). Pangan.com eBooks.

Kirnadi, A.J, Zuraida, A., Ilhamiyah. (2014). Survey of soil fertility in the farmland of Tidal Land Farms Banjar Regency. Media Sain, 7(1), 5359.

Krisnohadi, A. (2011). Analysis of the development of peatlands for oil palm in the Kubu Raya Regency. Journal of Plantation Engineering, 1 (1), 1-7.

Nagur, Y.K. (2017). Study of the Relationship of Soil Organic Materials to Rice PlantLandProductivity in Kebonagung Village. Thesis. Agrotechnology Study Program, Faculty of Agriculture, National Development University "Veterans". Yogyakarta.
Najiyati, S., Muslihat, L. \& Suryadiputra. (2004). Guide to Peatland Management for Sustainable Agriculture. Wetland International-Indonesia Program.

Manurung, R., Gunawan, J., Hazriani, R. \& Suharmoko, J. (2018). Mapping the status of soil N, P and K nutrients in oil palm plantations on peatlands. $\mathrm{Pe}$ don Tropical Journal, 1(3), 89-96)

Nugroho, W.P. (2015). Determination of leaf color standards as an effort to identify the nutrient status $(\mathrm{N})$ of maize (Zea mays L.) on regosol soils. Planta Tropics Journal of Agro Science, 3(1), 9-15

Nurhayati. (2013). Effect of ameliorant types on the effectiveness and infectivity of microbes in peat soils with soybean as an indicator plant. Floratek, 40(6), 124-139.

Maas, A., Kabirun, S. \& Nuryani, S. (2000). The rate of peat decomposition and its impact on nutrient status at various leaching levels. J. Soil and Environmental Sciences, 2(1),23-32

Makarim, A.K., Suhartatik, E. \& Kartohardjono, A. (2007). Silicones: Important Nutrients in Rice Production Systems. Food Crop Science and Technology, 2(2), 195-204.

Mario, M.D. (2002). Increased Peat Soil Productivity and Stability with Provision of Mineral Soil Enriched by High Iron Material. Post-graduate Program Dissertation, Bogor Agricultural Institute, Bogor.

Mengel, K. \& Kirkby, E.A. (2007). Principles of Plant Nutrition. Inter Potash Inst. WorblaufenBern, Switzerland.

Noor, M. (2001). Peatland Agriculture: Potential and Constraints. Kanisius, Yogyakarta.

Rauf, AW, Syamsudin, T. \& Sihombing, SR. (2000). The Role of NPK Fertilizers on Rice Plants. Agriculture Department, Irian Jaya.

Rachim, A. (1995). The use of polyvalent cations in relation to the availability of phosphate to increase corn production in peat soils. Doctoral Dissertation of IPB Postgraduate Program

Ritung, S., Wahyunto, Agus, F. \& Hidayat, H. (2007). Evaluation of Land Suitability with Example Maps for Directions for Land Use in West Aceh Regency. Center for Soil Research and the World Agroforestry Center.

Riyandani, D. (2016). Evaluation of Land Suitability for Various Types of Plants in Peatlands in Arut Selatan District, Kotawaringin Barat District. Faculty of Geography, Muhammadiyah University, Surakarta.

Ratmini, S. (2012). Characteristics and management 
of peatlands for agricultural development. Journal of Suboptimal Land,1(2), 197-206.

Salsi, I. (2011). Characterization of peat with various ameliorant materials and their effects on physical andchemicalpropertiestosupportpeatlandprodu ctivity. Agrovigor Journal,1(4),42-50.

Sani. (2011). Making Activated Carbon from Peat soils. Journal of Chemical Engineering 5(2), 1 $-12$

Soewandita, H. (2008). Study of soil fertility and land suitability analysis for estate crop commodities in Bengkalis Regency. J. Science and Technology. 10(2), 128-133.

Suliartini, N.W.S., Sadimantara, G.R., Wijayanto, T., Muhidin. (2011). Testing anthocyanin levels of upland brown rice from the Southeast Sulawesi germplasm collection. Agro Crop. 4(2), 43-48.

Suriadikarta, D.A., Prihatini, T., Setyorini, D. \& Hartatiek, W. (2002). Management of Soil Organic Materials Technology 339 - 358. In Dry Land Management Technology Towards Productive and Environmentally Friendly Agriculture. Center for Land and Agroclimate Research and Development, Bogor.

Syamsiyah, J., Suhardjo, M. \& L. Andriyani. (2009). The efficiency of $\mathrm{P}$ fertilizer and rice yield (Oryza sativa L.) in Kulonprogo beach sand rice fields which were given zeolites. Scientific
Journal of Soil Science and Agro-Climatology, 6(1), 7-13.

Susandi,Oksana, \& Arminudin, A.T. (2015). Analysis of the physical properties of peat soils in peat forests in Tambang District, Kampar Regency, Riau Province. Journal of Agrotechnology. 5 (2), 23-28.

Wati, Y,T., Fahri, Nurmauli, N. \& Syam, T.(2013). Evaluation of the suitability of paddy fields on irrigated paddy fields. J. Tropical Agriculture. 1(2), 222-225.

Wahyunto, Ritung, S., Suparto, \& Subagjo, H. (2005). Peat Land Distribution and Carbon Content in Sumatra and Kalimantan. Wetland International-Indonesia Program and Wildlife Habitat Canada (WHC). Bogor-Indonesia.

Waluyo \& Djamhari, S. (2011). Soil chemical properties and land suitability in each typology of lebak swamp for rice cultivation, a case in Tanjung Elai Village, Ogan Komering Ilir. Indonesian Journal of Science and Technology. 13(3), 204-209.

Winarso, S. (2005). Soil Fertility, Basic Health, and SoilQuality. Gava Media, Yogyakarta.

Widjaja Adi, I.P.G. (1992). Development of a deep tropical peatland for perennial crops. InAminuddin et al. (Eds) Proceeding of the International Symposium on Tropical Peatland, Kuching Sarawak Malaysia. 